\title{
SYRIAN MIGRATION AND TURKISH LABOR MARKET: ANALYSIS OF THE ECONOMIC EFFECTS
}

\author{
Fatih Ayhan \\ Bandirma Onyedi Eylul University, Balıkesir,Turkey \\ Pınar Fulya Gebeşoğlu \\ Ministry of Treasury and Finance, Ankara, Turkey
}

Migration is a multifaceted problem with social, economic and political dimensions. Following the Arab Spring, Turkey has experienced very strong migration flows from Syria since March 2011. Due to its humanity dimensions, the problem of migration has become a problem that requires taking measures on the global scale. Republic of Turkey has assumed considerable responsibility to host Syrian immigrants. As immigrants to Turkey exceeds over $3.5 \mathrm{mln}$ people, various policy measures are taken with regard to incoming Syrian immigrants. Adaptation of these migrants at the job market has many obstacles. This research aims to examine the effects of immigration on economy. The global economic effects of immigration are analysed by means of using detailed statistical data. Considering the theories stressing the importance of immigration as an opportunity that creates significant changes in social structure, the migration theories are discussed, causes and economic effects of migration are analysed.

Keywords: global migration flows; Syrian civil war; immigration; economic dimension of migration; labor market; migration policy

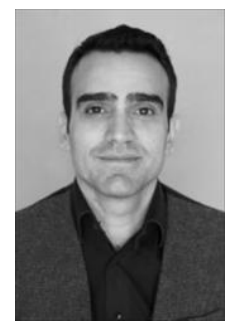

\section{Fatih Ayhan}

Dr., Asst. Prof., Bandirma Onyedi Eylul University, Balıkesir, Turkey.

He obtained his B.A. Degree in Economics from Balikesir University in Turkey then he completed M. S. Degree at Balikesir University. He got his Ph.D. in Economics from Selcuk University in 2016.

His research interests are on labour market, monetary policies, international economics and EU Integration. He's working as a lecturer at the Bandirma Onyedi University in Turkey. He has several class about economics in undergraduate students.

E-mail: fatih_ayhan@yahoo.com

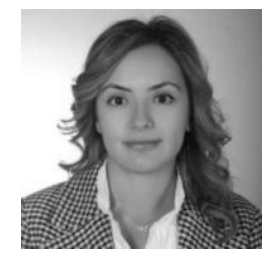

\section{Pınar Fulya Gebeşoğlu}

Dr., obtained her B.A. Degree in Economics from Bilkent University then completed M.S. Degree at Texas A and M University. She got Ph. D. in Economics from Gazi University in 2014.

Her research interests are on business cycles, financial crises, open economy macroeconomics issues in emerging and developing economies. She had a class about Economic Crises course for graduate students enrolled in Financial Economics master's program at Çankaya University.

E-mail: pf_gebesoglu@yahoo.com 


\section{Introduction}

Migration is an act of individual or collective displacement between countries or regions. The migration movement, which is also called population movement, can be defined as the movement of people with the intention to leave the country of origin due to political and economic reasons and take refuge in other countries. There can be many political, religious, economic, cultural and social factors encouraging migration flows. During mass migration flow taking place between the borders, the host country is also receiving various economic, political, cultural and social problems. The way to combat all these kinds of problems arising from migration flows is through interdisciplinary studies and cooperation.

When fundamental human needs such as security, shelter and nutrition are not properly met in one's own country individuals may choose to go beyond borders by using various channels, legal and illegal ones. Therefore, migration flows either depend on personal preferences of individuals, or arise as a necessity compelled by political and economic conditions in the country of origin. The most common migration factors include the desire to escape natural disasters, conflict or war, to avoid political and economic tensions within the country and to increase own prosperity and welfare.

According to theories that link migration movement to economic conditions, the wage differences between two countries stimulate migration. The labor force, in search of higher welfare incline to countries with higher wage opportunities. Therefore, the inadequacy of domestic labor supply in the countries where labor demand is higher triggers labor force movements. Along with the changing global conditions, the demand for highly qualified human capital has increased, as compared to demand for unqualified labor. As developed countries demand highly skilled labor force, better working conditions, higher wages and better education opportunities in developed countries evoke migration movement which is frequently described as brain drain.

Labor market conditions trigger migration flows. The fact that there are not enough job opportunities in emerging countries creates migration pressure on millions of young men and women every year. Growing population entering the labor force in emerging countries and aging population and labor shortages in developed countries creates labor migration flows from former countries to the latter. In addition, with the development of communication technologies, easier access to information about the global labor market triggers labor flows from other countries (ILO, 2014:16).

Violence, oppression, war, terrorism and long-lasting political and economic instability are the main reasons for forced migration. In other words, individuals who want to be happier, peaceful, safe or to have higher standards of living and seek prosperity can leave their countries for high income, even if this means undertaking great risks. However, getting used to new conditions, finding opportunities, inclusion into the local community can be both challenging and time consuming. The world wars of the previous century, wars and conflicts in the Middle East, disintegration of the USSR, invasion of Afghanistan, tension on the Balkans and the recent Arab spring events are among the events that have led to significant mass migration.

Turkey has experienced very strong migration flows from Syria following the Arab Spring of March 2011. Due to its humanitarian dimensions, the problem of migration has become a problem that requires taking measures on the global scale. Republic of Turkey has undertaken the responsibility to host Syrian refugees. Turkey's economy has a major problem 


\section{SYRIAN MIGRATION AND TURKISH LABOR MARKET}

about the Syrian refugees whose number already exceeds 3.5 million. Thus, it becomes imperative to take serious political and economic measures regarding Syrian immigration.

This study aims to discuss the reasons behind migration movement, its effects on economies and the related policy recommendations. Theoretical explanations of migration movements are explored and recent changes in the global migration statistics are analyzed. The study also examines how Turkish labor market is affected by Syrian immigrant flows. The study provides both statistical indicators and policy recommendations on integration of the immigrants into the economy.

In the following parts of the study theoretical definitions of migration will be introduced and types of migration will be discussed. Then, a brief summary of migration theories will be presented and the effects of migration on economies will be analyzed. Finally, global migration statistics will be used to highlight the distribution and economic size of migration across the world and in the case of Syrian refugees at Turkish labor market in particular.

\section{The Case of Syrian Refugees in Turkey}

Since its foundation, Turkey has significant exposure to massive migration flows at different times. According to Turkey Migration Administration (2019) data, the most significant migration inflows to Turkey that took place in history were the following:

- 384,000 people from Greece with the population exchange between 1922-1938,

- 800,000 people from the Balkan countries between 1923 and 1945,

- 800,000 people from Germany between 1933 and 1945,

- 51,542 people from Iraq after the Halabja massacre in 1988,

- 345,000 people from Bulgaria in 1989,

- 467,489 people from Iraq after the First Gulf War in 1991,

- 20,000 people from Bosnia and Herzegovina between 1992-1998,

- 17,746 people from Kosovo in 1999 ,

- 10,500 people from Macedonia in 2001,

- approximately $3.6 \mathrm{mln}$ people due to internal turmoil in Syria during April 2011March 2019.

After the so-called "Arab Spring" back in 2011, Tunisia, Libya, Egypt and Syria became the most affected countries. This development led to the largest migration flows to the surrounding countries and the whole world witnessed the severe crisis in Syria as a result of internal conflicts. After the Arab Spring approximately $3.6 \mathrm{mln}$ immigrants sought asylum in Turkey. Since the World War II, this was the largest migration phenomenon in the related region. Turkey's domestic policy on healthcare, education, security, social rights, shelter and labour market, all have been significantly influenced by this crisis.

According to the Republic of Turkey Ministry of Interior Directorate General of Migration Management's (MIDGMM) database, the total registered Syrians in Turkey, as of April 11, 2019 reached 3 million 621 thousand 330 people. 1 million 962 thousand 966 of these people are men, and 1 million 658 thousand 364 are women (see Tab. 1, 2). 2.1 million Syrian refugees in Turkey are within the working age population, that is, aged 15+. The average age of the Syrians in Turkey is 22,5. Noteworthy, the average age of the Turkish in Turkey is 31,7. The number of male Syrians is much higher than that of female Syrians. 
The number of registered Syrians decreased by 1.862 persons between December 31, 2018 and April 2019. As of 11 April 2019, the number of the Syrians living in temporary protection centers is 139 thousand 150. Only 3.84\% of the Syrians in Turkey are living in camps.

Table 1- Summary Information on Syrian Immigrants Living in Turkey (as of 2019)

(Source: MIDGMM, 2019)

\begin{tabular}{|c|c|c|c|}
\hline Age & Male & Female & Total \\
\hline TOTAL & 1.962 .966 & 1.658 .364 & $\mathbf{3 . 6 2 1 . 3 3 0}$ \\
\hline $0-4$ & 258.894 & 241.875 & $\mathbf{5 0 0 . 7 6 9}$ \\
\hline $5-9$ & 257.350 & 242.267 & $\mathbf{4 9 9 . 6 1 7}$ \\
\hline $10-14$ & 200.861 & 186.204 & $\mathbf{3 8 7 . 0 6 5}$ \\
\hline $15-18$ & 148.675 & 122.948 & $\mathbf{2 7 1 . 6 2 3}$ \\
\hline $19-24$ & 318.799 & 228.991 & $\mathbf{5 4 7 . 7 9 0}$ \\
\hline $25-29$ & 206.992 & 146.894 & $\mathbf{3 5 3 . 8 8 6}$ \\
\hline $30-34$ & 171.237 & 125.251 & $\mathbf{2 9 6 . 4 8 8}$ \\
\hline $35-39$ & 121.273 & 95.337 & $\mathbf{2 1 6 . 6 1 0}$ \\
\hline $40-44$ & 80.161 & 70.537 & $\mathbf{1 5 0 . 6 9 8}$ \\
\hline $45-49$ & 59.379 & 56.408 & $\mathbf{1 1 5 . 7 8 7}$ \\
\hline $50-54$ & 48.103 & 45.867 & $\mathbf{9 3 . 9 7 0}$ \\
\hline $55-59$ & 33.498 & 33.718 & $\mathbf{6 7 . 2 1 6}$ \\
\hline $60-64$ & 23.463 & 24.099 & $\mathbf{4 7 . 5 6 2}$ \\
\hline $65-74$ & 24.309 & 25.465 & $\mathbf{4 9 . 7 7 4}$ \\
\hline $75+$ & 9.972 & 12.503 & $\mathbf{2 2 . 4 7 5}$ \\
\hline
\end{tabular}

As of April 11, 2019, the number of the Syrians living in Turkish cities was 3 mln 482 thousand 180. Thus, $96.16 \%$ of the Syrians live in cities. According to the data of the Migration Administration as of 11 April 2019, most of the Syrian refugees are living in 20 cities only, see Tab. 2 for more details.

The city with the most Syrian hosts is Istanbul with 553 thousand 387 people, while the city with the least number of the Syrians is Bayburt, 25 people only. According to the latest census of the TURKSTAT, Turkey has the overall population of 82.003.882. Turkey has taken under temporary protection the Syrians who are currently registered as $4.41 \%$ of the population.

Fig. 1 shows the cities where most of the Syrians reside in Turkey. According to this map and official statistics overall, the cities with the highest number of the Syrians are Istanbul, Sanliurfa, Hatay, Gaziantep, Adana, Mersin, Bursa, Izmir, Kilis and Konya. Many 


\section{SYRIAN MIGRATION AND TURKISH LABOR MARKET}

of these cities are close to the Syrian border, other cities have many job opportunities. There two facts are noteworthy.

Table 2 - Provincial Breakdown of the Syrians living in Turkey (as of 2019)

(Source: MIDGMM, 2019)

\begin{tabular}{|c|c|c|}
\hline Province & $\begin{array}{c}\text { Number of the } \\
\text { Syrians }\end{array}$ & $\begin{array}{c}\text { Share in the Province } \\
\text { Population, in \% }\end{array}$ \\
\hline İstanbul & 553387 & 3,67 \\
\hline Şanliurfa* & 447622 & 21,99 \\
\hline Hatay* & 43446 & 26,96 \\
\hline Gaziantep* & 428724 & 21,13 \\
\hline Adana* & 236362 & 10,65 \\
\hline Mersin & 203502 & 11,22 \\
\hline Bursa & 169205 & 5,65 \\
\hline İzmir & 142740 & 3,30 \\
\hline Kilis* & 115987 & 81,37 \\
\hline Konya & 106227 & 4,82 \\
\hline Ankara & 90751 & 10,64 \\
\hline Mardin & 88222 & 7,68 \\
\hline Kahramanmaraş & 87942 & 1,65 \\
\hline Kayseri & 77995 & 5,61 \\
\hline Kocaeli & 55941 & 2,93 \\
\hline Osmaniye* & 48763 & 9,12 \\
\hline Diyarbakır & 33648 & 1,94 \\
\hline Malatya & 29669 & 3,72 \\
\hline Adiyaman & 24589 & 3,94 \\
\hline & & \\
\hline
\end{tabular}

According to the Ministry of Interior of Turkey, the number of the Syrians granted Turkish citizenship as of March 8, 2019 was 79 thousand 894 people. As of November 2018, the number of Syrian babies born already in Turkey (during the last 8 years) was 405521 . According to the Ministry of Family, Labour and Social Services of Turkey, the number of the Syrians granted work permits in Turkey, as of 15 November 2018, was 32199 people. 


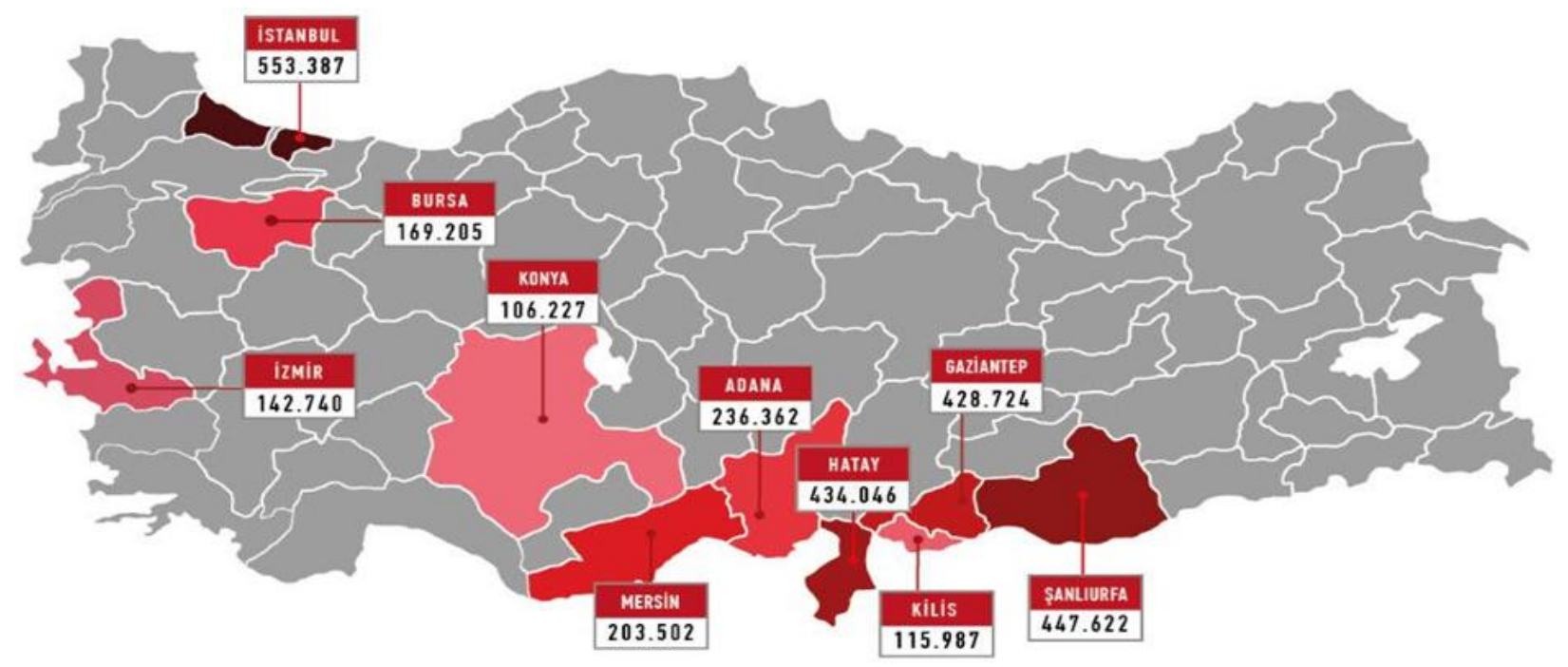

Figure 1 - Cities with the Largest Numbers of Syrian Immigrants in Turkey (2019)

\section{Challenges Related to Syrian Migrants at the Labour Market of Turkey}

Syrian migrants face a number of problems when it comes to Turkish labour market. In addition to the negative image of being seen as a foreigner in a different country, they cannot integrate into the local job market due to several bureaucratic problems, even if they find suitable job positions. Despite all the cultural and social similarities between Turkey and Syria, we can still observe exclusion at the labour market.

One of the most serious bureaucratic obstacles for Syrian refugees are Turkish labour market is the issue of diploma equivalent as it hinders finding suitable work. In addition, Syrian migrants do not have work permissions, their education level is usually low, they cannot speak Turkish and they are not accepted by the local people. All these factors taken together eventually make Syrian immigrants cheaper labour force for Turkish employers. It is noteworthy that Syrian migrants are employed in the sectors where demand for unskilled labour is high, particularly, in the agricultural and construction sectors (Duruel, 2017). And there are also employers employing Syrian migrants as subcontractors. Besides, the majority of Syrian refugees in Turkey are actually teenagers and children. Thus, many of Syrian migrants have to start working early and contribute to family budget.

In order to be able to work in Turkey, all foreigners need to have at least a valid passport. And in order to have a residence permit the employer should have documented that a position is reserved for foreign labour because it cannot be filled by local labourers. Such bureaucratic problems constitute an important problem for finding jobs for Syrian refugees (Kiriş̧̧i, 2014).

Syrian migrants cannot work in hospitals, academies and other educational institutions because of the problem with their diploma equivalence, even when their level of education and qualifications is really high. 


\section{SYRIAN MIGRATION AND TURKISH LABOR MARKET}

Employment of the Syrians increases competition with the domestic workers. This situation is experienced in every province of Turkey and in nearly all sectors where domestic labour force meets Syrian labour force. This competition leads to lower working conditions for the domestic labour force. This creates the perceptions that the Syrians take away the work of the local population (Kaygisiz, 2017).

Another serious challenge related to Turkey's Syrian refugees concerns the increase in government spending due to the increasing demand for infrastructure and public services because of the increasing numbers of Syrian refugees. Turkey's situation with Syrian refugees doesn't get enough attention and support from international organizations and other countries. Thus, the cost of Syrian refugees on Turkish economy is increasing continuously.

Syrian refugees are mostly oriented towards jobs that Turkish citizens do not want to do. The Syrians generally fill in the gap between unqualified workers in the seasonal sectors and provide full capacity to work in these sectors (Koyuncu, 2016: 110).

The situation with Syrian immigrants, who are perceived as threatening because of their cheap labour force, disrupts the structure of the whole labour market. In literature, the basic point of the theory, which is known as the split labour market theory, emphasizes on the two-layered structure arising from capital-intensive works and labour-intensive works in developed countries.

Migration, in this context, is directed by the demand for low-level workforce for the jobs that are not accepted by domestic workers (Lordoğlu, Kıroğlu and Tanyılmaz, 2004: 10). In this sense, the Syrians do not take away the local business opportunities, but rather cover the gap in businesses that require unskilled labour (Koyuncu, 2016: 115).

There are some empirical studies about the effects of Syrians refugees on Turkish labour market. Their findings are quite different and the general findings obtained from these studies can be summarized as follows:

Akgündüz, Berg and Hassink (2015), found that Syrian refugees did not have any impact on local employment, however, some groups at the regional level (groups with low levels of education and skills) produced limited but negative effect.

Ceritoglu et al. (2015) suggested that only Syrian refugees are observed on the unregistered employment level in Turkey. According to the findings of this study, Syrian refugees decreased by approximately 2.2 percentage points in informal employment and the local people with the lowest level of education were affected.

Bahçekapılı and Çetin (2015) analysed the relationship between the Syrian refugee's effects on unemployment rate, inflation, foreign trade and interior migration in Turkey. They found that Syrian refugees caused an increase in the unemployment rate and reduction in the price level in the studied region.

Del Carpio and Wagner (2015) examined Syrian immigrants' effects on Turkey's labour market. According to their results, Syrian migrants are predominantly informally employed and create the labour supply shock at Turkish labour market. Due to the unregistered employment of Syrian migrants, the number of registered domestic workers increased. Women and highly skilled labour are employed at low cost and unregistered. Women and low educated were found to be employed informally and with low wages.

Lordoğlu and Aslan (2015) found that refugees increased the unemployment rates in the informal sectors. On the other hand, Ceritoglu et al. (2015) found that in part of registered 
employment, some new employment areas were created and new firms were established to cater for the needs and services of Syrian refugees.

Esen and Binatl (2017) analysed the effects of Syrian refugees on the unemployment rate, informal and formal employment in 26 regions of Turkey using the regression models. According to the results of their study, Syrian refugees increase unemployment rate and reduce formal and informal employment.

\section{Conclusion}

The increasing number of migrants on the global scale has motivated this and many other analyses of economic and social impacts of immigration. Several theories have been developed in this regard suggesting that migration can have both positive and negative effects on economies. Diversity of both domestic and exogenous factors affecting migration is also crucial in exploring the consequences of labour force movements. According to the UN statistics, the number of migrants on the global scale reached $257.7 \mathrm{mln}$ as of 2017. Some of this migration has been triggered by natural disasters, wars, terrorism, political tension and other conflicts. In other cases, it was motivated by the hope of finding a wellpaid job, reaching better life standards and getting better education opportunities. Constantly changing factors that affect migration on the global scale indicate that migration flows will continue to exist as a global trend of top priority in the near future.

A number of measures should be taken to combat with the adverse consequences of international migration. First, a fair and effective international organization must be established to end wars and conflicts on the global scale and ensure that countries comply with such decisions. Sanctions and measures should be taken to improve the international legal system. A fairer economic system could smooth income inequalities between the countries. More active poverty prevention programs should be implemented on the global scale. Local measures to improve working conditions and provide better healthcare and education opportunities should be encouraged. Cooperation against terrorism should become really global one (Semercioglu, 2017). Global opportunities to ensure that people live in dignity should be made prevalent to a largest geographical extent possible. Most importantly, fighting against poverty, enhancing security and welfare in workplaces and in access to education opportunities should become a truly global interest of all.

\section{References:}

Bahçekapıl1, C., and Çetin B. (2015). The Impacts of Forced Migration on Regional Economies: The Case of Syrian Refugees in Turkey. International Business Research, 8: 1-15.

Ceritoglu, E., Gurcihan H.B.,Yunculer, Torun H., and Tümen S.(2015). The Impacts of Syrian Refugees on Natives' Labor Market Outcomes in Turkey: Evidence from a Quasi-experimental Design. Central Bank Report, Ankara.

Del Carpio X.V. and Wagner M. (2015). The Impact of Syrian Refugees on the Turkish Labor Market, World Bank Group, Social Protection and Labor Global Practice Group, Policy Research Working Paper, 7402.

Duruel, M. (2017). The Effects Syrian Refugees On the Turkish Labor Market: Opportunities And Threats, International Journal of Economic Studies, 3(2), 207-222.

Esen, O. and Binatl1, A.O. (2017). The Impact of Syrian Refugees on the Turkish Economy: Regional Labour Market Effects, Social Sciences, 6, 129-141. 


\section{SYRIAN MIGRATION AND TURKISH LABOR MARKET}

EUROSTAT (2019). Migration and Migrant Population Statistics: Statistics Explained, Retrieved from: https://ec.europa.eu/eurostat/statistics-explained/pdfscache/1275.pdf. (Accessed at: 01.04.2019)

ILO (2004). Towards a fair deal for migrant workers in the global economy, International Labour Conference, 92nd Session, International Labour Office Geneva. ISBN 92-2-113043-6.

ILO (2018). ILO Global Estimates on International Migrant Workers - Results and Methodology. 2nd ed. International Labour Office - Geneva.

ILO (2019). International Labour Standards on Migrant workers, International Labour Organisation, Retrieved from: https://www.ilo.org/global/standards/subjects-covered-byinternational-labour-standards/migrant-workers/lang--en/index.htm (Accessed at : 01.04.2019)

International Organisation for Migration (2017). Migration Flows-Europe, The UN Migration Agency.

Kaygisiz, I. (2017). The Effects of Syrian refugees on Turkey Labor Market (In Turkish), FriedrichEbert-Stiftung Press, Beșiktaş-Istanbul.

Kirişci, K.(2014). Syrian Refugees and Turkey's Challenges: Going Beyond Hospitality, The Brookings Institution, Massachusetts Avenue, N.W., Washington Institute.

Koyuncu, A. (2016). Blessing? Ashes? Syrian Refugee and Migration Turkey's Economy (In Turkish). In: Temporary Protected Syrians in Turkey: Assessment and Recommendations, (Edts: Adem Esen, Mehmet Duman), Demokrasi Akademisi Vakfi Press, İstanbul.

Lordoğlu, K. Kıroğlu, M. M. And Tanyılmaz, K. (2004). Informal Employment and Foreign Illegal Labor Force in Turkey(In Turkish). Uginar Project Report, İstanbul.

Lordoğlu, K., and Aslan, M. (2015). Five Border Cities and Change in Labor Markets: 2011-2014. Journal of Migration, 2(2), 249-267.

MIDGMM (2019). Migration Statistics and History In Turkey, Republic of Turkey Ministry of Interior Directorate General of Migration Management, Ankara-Turkey.

Paper submitted

Paper accepted for publishing

Paper published online
12 October 2019

26 November 2019

05 February 2020 